\title{
SISTEM INFORMASI GEOGRAFIS JARINGAN IRIGASI DINAS BINA MARGA DAN PENGAIRAN KABUPATEN ROHIL
}

\author{
Imam Rangga Bakti ${ }^{1}$ \\ ${ }^{1}$ Sistem Informasi, Universitas Tjut Nyak Dhien, Jl. Gatot Subroto/ Jl. Rasmi No.28 Kota Medan \\ email: imamranggabakti@gmail.com
}

\begin{abstract}
Abstrak
Sistem informasi Geografis (SIG) sudah banyak digunakan serta dimanfaatkan oleh instansi instansi swasta maupun instansi pemerintahan terhadap keperluan pemantauan, perencanaan, serta evaluasi dari hasil hasil pembangunan. Salah satu instansi yang memerlukan perkembangan Sistem Informasi Geografis (SIG) yaitu Dinas Bina Marga dan Pengairan Kabupaten Rohil dimana penyajian informasi dalam jaringan irigasi pada Dinas Bina Marga dan Pengairan Rohil masih memerlukan perkembangan dalam kegiatan mempermudah perbaikan serta penambahan jaringan irigasi yang belum terkoordinir dan memberikan informasi mengenai informasi data serta lokasi jaringan irigasi yang dapat mempermudah pihak dinas bina marga dalam mendapatkan informasi. Penelitian ini menggunakan tahapan penelitian analisa masalah, pengumpulan data dengan cara observasi, studi literatur, dan wawancara. Setelah itu melakukan analisis kebutuhan sistem dan perancangan sistem yang meliputi perancangan proses, perancangan database, perancangan struktur menu dan perancangan interface. Selanjutnya implementasi sistem dengan memanfaatkanVB.Net, MySql dan ArcGis dan Crystal Report sebagai aplikasinya. Hasil dari penelitian ini berupa penampilan peta, inforrmasi informasi jaringan irigasi dan informasi informasi laporan data dalam keperluan sesuai kebutuhan Dinas Bina Marga dan Pengairan Kabupaten Rohil.
\end{abstract}

Kata Kunci: SIG, Jaringan Irigasi, VB.Net, MySql, ArcGis

\begin{abstract}
Geographical information systems (GIS) have been widely used and used by private agencies and government agencies for monitoring, planning, and evaluation of the results of development. One agency that needs the development of a Geographic Information System (GIS), namely the Office of Highways and Irrigation of Rohil Regency where the presentation of information in the irrigation network at Rohil's Highways and Irrigation Service still needs development in facilitating improvements and adding irrigation networks that are not yet coordinated and providing information on data information and the location of irrigation networks that can facilitate the bina marga office in obtaining information. This study uses the stages of problem analysis research, data collection by observation, literature study, and interviews. After that, do a system requirements analysis and system design which includes process design, database design, menu structure design and interface design. Next is the system implementation using VB.Net, MySql, ArcGis and Crystal Report as the application. The results of this study were in the form of map appearance, information on irrigation network information and information on information on data reports in accordance with the needs of the Office of Highways and Irrigation of Rohil Regency.
\end{abstract}

Keywords: GIS, Jaringan Irigasi, VB.Net, MySql, ArcGis

JURSIMA https://ejournal.giciku.ac.id/

Jurnal Sistem Informasi dan Manajemen 
Volume 7 No. 1

Mei 2019

\section{PENDAHULUAN}

Peran serta perkembangan teknologi informasi tidak bisa dipungkiri saat ini sudah jauh berkembang pesat sehingga sangat mudah dalam mengaksek informasi baik melalui televisi, handphone serta internet. Dengan kemudahan dalam mengakses informasi mendorong manusia untuk mengembangkan salah satu teknologi informasi yanitu SIG (Sistem Informasi Geografis). Sistem Informasi Geografis merupakan sebuah sistem informasi khusus yang mana mengelola data data yang mempunyai informasi spasial atau bereferensi keruangan.

Pengertian informasi geografis adalah informasi mengenai tempat atau lokasi, dimana suatu objek terletak di permukaan bumi dan informasi mengenai objek dimana lokasi geografis itu berada untuk dianalisa dalam pengambilan keputusan.

Sistem informasi Geografis sudah banyak digunakan serta dimanfaatkan oleh instansi instansi swasta maupun instansi pemerintahan terhadap keperluan pemantauan, perencanaan, serta evaluasi dari hasil hasil pembangunan.

Salah satu instansi yang memerlukan perkembangan Sistem Informasi Geografis yaitu Dinas Bina Marga dan Pengairan Kabupaten Rohil dimana penyajian informasi dalam jaringan irigasi pada Dinas Bina Marga dan Pengairan Rohil masih memerlukan perkembangan dalam kegiatan mempermudah perbaikan serta penambahan jaringan irigasi yang belum terkoordinir dan memberikan informasi mengenai informasi data serta lokasi jaringan irigasi yang dapat mempermudah pihak dinas bina marga dalam mendapatkan informasi.

Untuk mengatasi permasalahan yang ada, penerapan sistem informasi geografis

JURSIMA https://ejournal.giciku.ac.id/

Jurnal Sistem Informasi dan Manajemen adalah langkah yang tepat agar bisa mengetahui informasi informasi jaringan irigasi yang ada di rohil, karena sistem informasi geografis memiliki kemapuan yang sangat luas serta baik dalam proses pemetaan dan analisis sehingga teknologi ini sangat sering dipakai dalam proses rencana tata ruang.

\section{METODE PENELITIAN}

Dalam metodologi penelitian ini peneliti memiliki tahapan tahapan metode yaitu tahapan tersebut digambarkan pada gambar dibawah ini

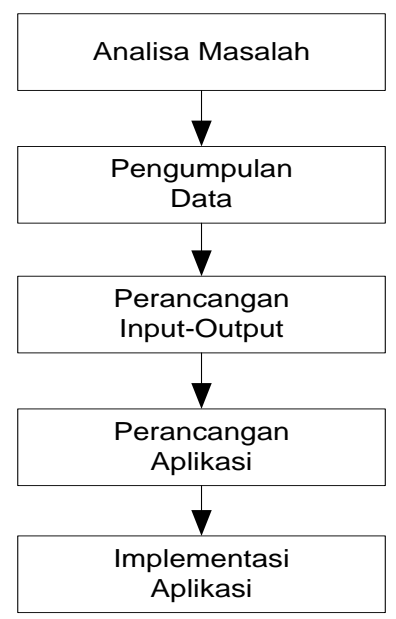

1. Analisa Masalah

Analisis masalah adalah suatu langkah yang memahami masalah dimana ruang lingkup telah ditentukan batasanya oleh penulis. Dengan menganalisa masalah yang telah dilakukan tersebut, maka diharapkan masalah dapat dipahami dengan baik.

\section{Pengumpulan Data}

yaitu pengumpulan data dan informasi yang dilakukan dengan cara mengamati langsung ke objek dan juga menganalisa sistem yang sedang 
ISSN 2338-1523

E-ISSN 2541-576X

Volume 7 No. 1

Mei 2019

berjalan, serta mengamati langsung Sitem Informasi Geografis

\section{Peracangan Input-Output}

Pada tahapan ini merancang inputoutput dengan menggunakan Aplikasi Visual Basic 10, crystal report umtuk membuat laporan, ArcGIS untuk membuat peta dan menggunakan Database MySQL dengan menggunakan tool pada program tersebut.

\section{Perancangan aplikasi}

Pada tahapan ini merancang Aplikasi Sitem Informasi Geografis Untuk Sistem Informasi Jaringan Irigasi pada Dinas Bina Marrga dan Pengairan Kabupaten Rohil. Dengan menggunakan, Aplikasi Visual Basic.NET, ArcGis dan Database MySQL.

\section{Implementasi aplikasi}

Pada tahap ini penulis mengimplementasikan Aplikasi Sitem Informasi Geografis Untuk Sistem Informasi Jaringan Irigasi pada Dinas Bina Marrga dan Pengairan Kabupaten Rohil.

\section{HASIL DAN PEMBAHASAN}

Aplikasi Sistem Informasi Geografis Jaringan Irigasi merupakan Aplikasi yang memuat informasi-informasi yang berhubungan dengan Sistem Informasi Geograsi Jaringan Irigasi pada Dinas Bina Marga dan Pengairan Kabupaten Rohil, mulai dari definisi, menampilkan aplikasi pemetaan irigasi, layanan yang disediakan berupa, peta, cetak laporan dan lain lain yang berhubungan dengan Jaringan Irigasi Dinas Bina Marga dan pengairan kabupaten Rohil

JURSIMA https://ejournal.giciku.ac.id/ Jurnal Sistem Informasi dan Manajemen
Hasil yang didapat sesudah melakukan pengujian program Sistem Informasi Geografia tersebut dapat dilihat dari tampilan tampilan program berikut :

\section{Menu login}

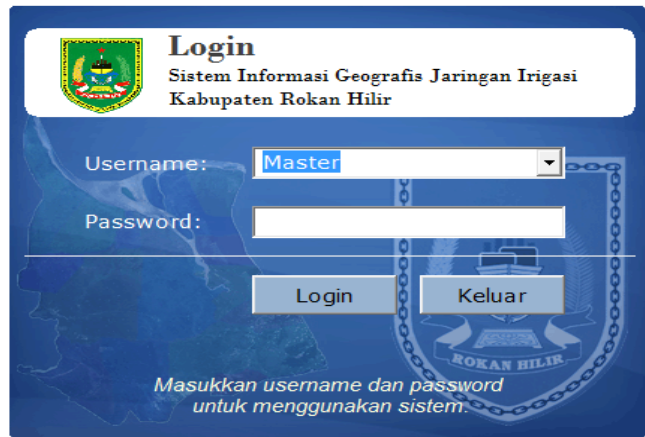

Gambar 1. Menu Login

Pada tampilan login ini berfungsi untuk masuk kedalam aplikasi Jaringan Irigasi dengan mengisi Username dan password yang telah disediakan.

\section{Menu Utama}

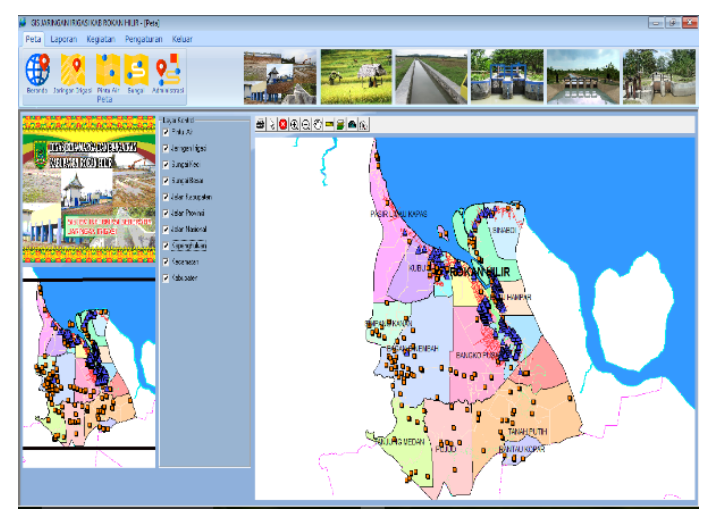

Gambar 2. Menu Utama

Tampilan menu utama setelah login terdapat menu menu dan sub sub menu tampilan peta yang berfungsi sesuai kebutuhan pengguna.

\section{Tampilan Informasi}


ISSN 2338-1523

E-ISSN 2541-576X

Volume 7 No. 1

Mei 2019

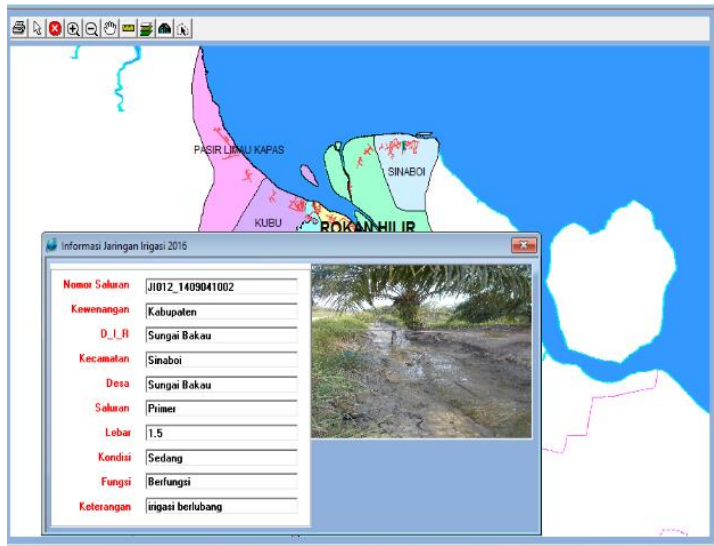

Gambar 3. Tampilan Informasi

Tampilan informasi akan menampilkan data informasi jaringan irigasi yang telah dipilih dari peta.

\section{Laporan Umum}

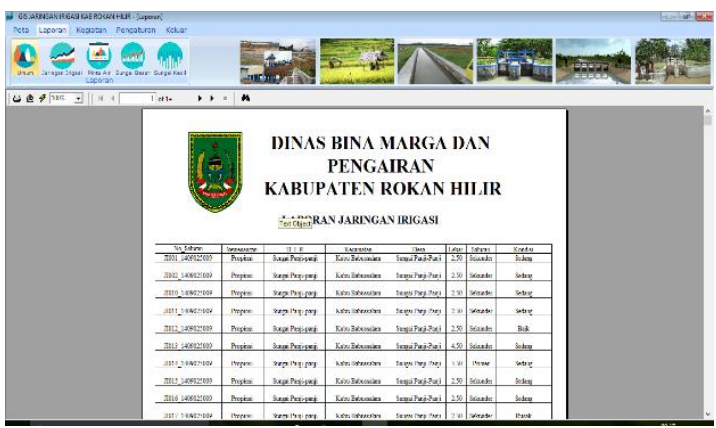

Gambar 4. Laporan Umum

Pada tampilan laporan umum ini menampilkan laporan secara keseluruhan atau umum yang terdapat pada jaringan irigasi rohil

\section{Laporan Jaringan Irigasi}

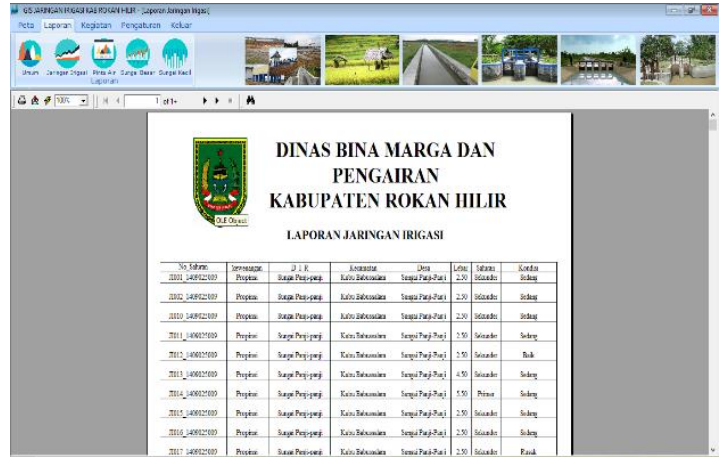

Gambar 5. Laporan Jaringan Irigasi

Pada sub menu laporan Jaringan Irigasi ini menampilkan laporan jaringan Irigasi

\section{Laporan Pintu Air}

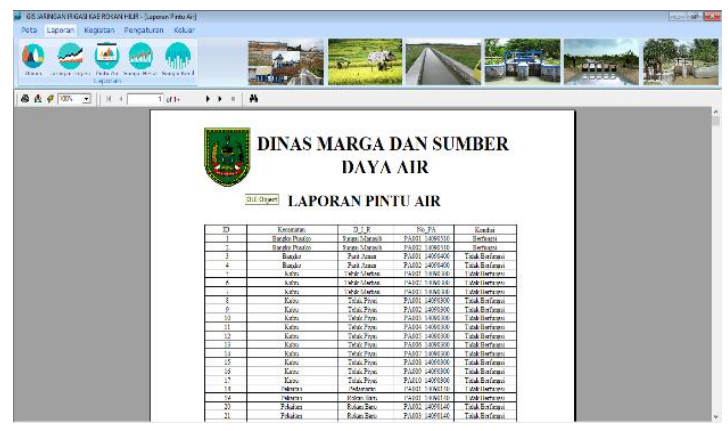

Gambar 6. Laporan Jaringan Irigasi

Pada sub menu Laporan Pintu Air ini menampilkan laporan Pintu Air

\section{Laporan Sungai Besar}

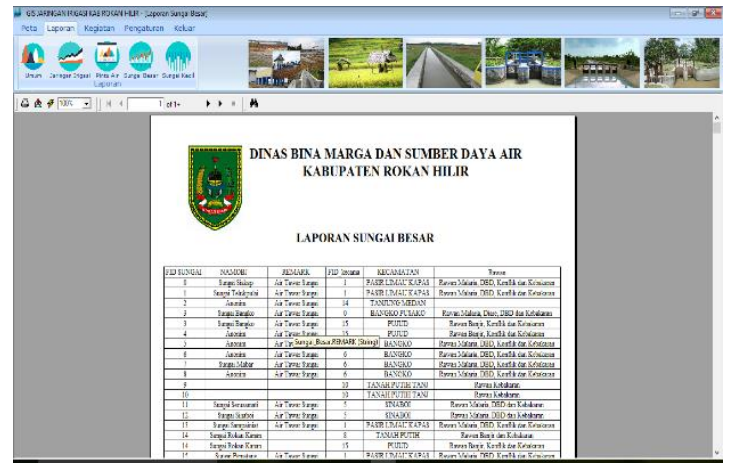

Gambar 7. Laporan Sungai Besar

Pada sub menu Laporan Sungai Besar menampilan laporan sungai besar

\section{Laporan Sungai Kecil}

JURSIMA https://ejournal.giciku.ac.id/ 
ISSN 2338-1523

E-ISSN 2541-576X

Volume 7 No. 1

Mei 2019

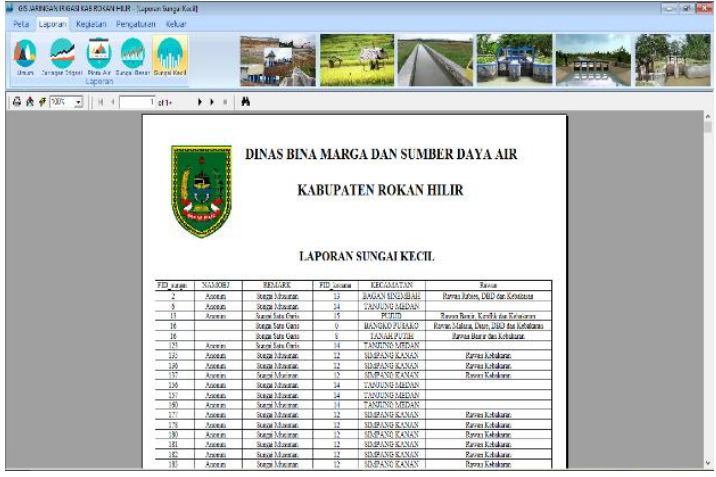

Gambar.8 Laporan Sungai Kecil

Pada sub menu Laporan Sungai Kecil menampilan laporan sungai kecil

\section{Menu kegiatan}

Di dalam menu kegiatan terdapat beberapa sub menu kegiatan

a. Rekap Kegiatan

Pada sub menu rekap kegiatan ini berfungsi untuk melakukan rekap data setiap kegiatan yang di lakukan.

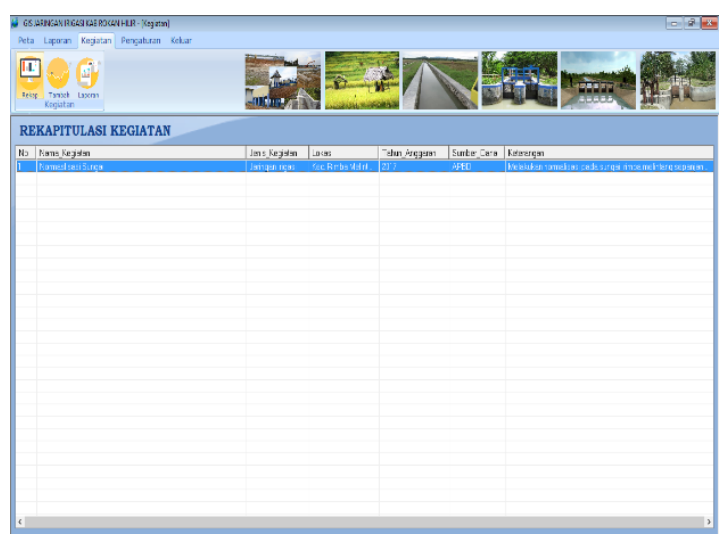

Gambar 9. Rekap Kegiatan

b. Tambah Kegiatan

Pada sub menu tambah kegiatan ini berfungsi untuk melakukan penambahan data setiap adanya kegiatan yang di lakukan

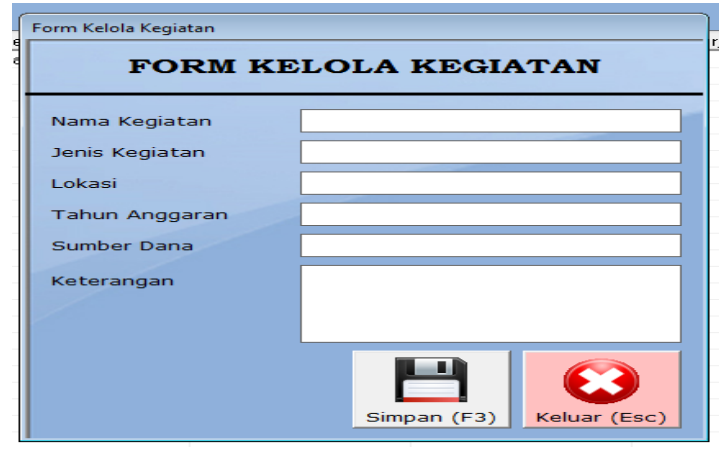

Gambar 10. Rekap Kegiatan

c. Laporan Kegiatan

Pada sub menu laporan kegiatan ini akan menampilkan laporan seluruh kegiatan yang telah ditambahakan pada menu tambah kegiatan.

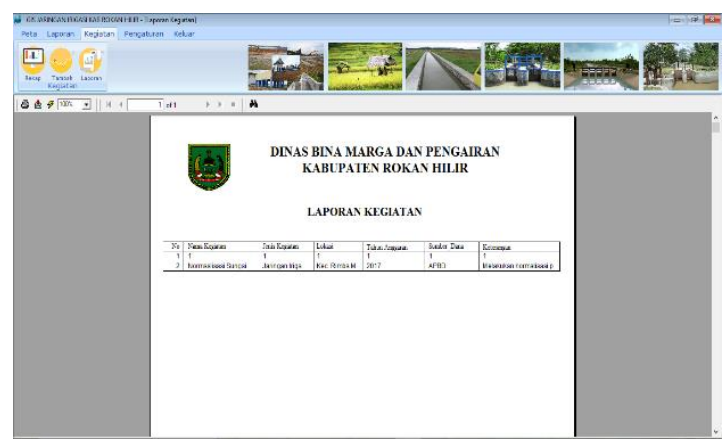

Gambar 11. Laporan Kegiatan

\section{SIMPULAN}

Dari hasil pengujian aplikasi yang dilakukan maka dari itu penulis menyimpulkan beberapa hal antara lain berikut:

1. Dengan aplikasi SIG ini bisa membantu dalam menampilkan wilayah, lokasi dan informasi dengan cepat.

2. Data yang ditampilkan sesuai dengan kebutuhan yang diperlukan

3. Data Informasi dapat dirubah sesuai dengan perubahan yang telah dilakukan dilapangan

JURSIMA https://ejournal.giciku.ac.id/ 
ISSN 2338-1523

E-ISSN 2541-576X

Volume 7 No. 1

Mei 2019

\section{UCAPAN TERIMA KASIH}

Terimakasih saya ucapkan untuk rekan rekan dan teman teman yag sudah membantu dalam melakukan penelitian ini

\section{DAFTAR PUSTAKA}

Harahap RR, Hidayatullah. 2018. Sistem Informasi Google Maps Dengan Menggunakan Vb.Net. I (1): 36 - 41

Maudi MF, Nugraha AL, Sasmito Bandi. 2014. Desain Aplikasi Sistem Informasi Pelanggan PDAM Berbasis WebGis (Studi Kasus : Kota Demak). Volume 3, Nomor 3

Tumimomor Mailany, Jando Emanuel, Meolbatak Emiliana. 2013. Sistem Informasi Geografis Kota Kupang. Volume 1, Nomor 2

Kharistian Erna, Ariwibowo Eko. 2013. Sistem Informasi Geografis Pemetaan Potensi Sma/Smk Berbasis Web (Studi Kasus : Kabupaten Kebumen). Volume 1, Nomor 1

Rahayu Siita, Piarsa Nyoman, Buana PW. 2016. Sistem Informasi Geografis
Pemetaan Daerah Aliran Sungai Berbasis Web. Volume 7, Nomor 2

Susanto Arief, Ahmad Kharis, Khotimah Tutik. 2016. Sistem Informasi Geografis Pemetaan Lahan Pertanian Dan Komoditi Hasil Panen Kabupaten Kudus. Volume 7, Nomor 10

JURSIMA https://ejournal.giciku.ac.id/ 